\title{
A Factor Analysis on the Determinants of Industrial Sickness in Small Scale Enterprises
}

\author{
Siva Krishna Golla* and K. Ramachandra Rao \\ School of Economics, University of Hyderabad, Telangana, India \\ *Corresponding author: sivakrishna883@gmail.com
}

\begin{abstract}
The study was conceptualized across the emerging small scale industry clusters and locations in the state of Andhra Pradesh in India. As evident, the SSI (small scale industry) plays a crucial role in macro and micro economic development in context of developing economy like India, yet the sector is not aloof from problems, challenges and threats evident as industrial sickness. The research posits across the socially constructed origins of the phenomenon and calls for the identification and classification of the factors that contribute towards industrial sickness in Andhra Pradesh SSI sector. The current research identifies the factors that contribute (directly and indirectly) towards the small scale industrial health(survival or decay) in Andhra Pradesh. At the same time, research seeks to quantify the cross factorial impact on organizational survival or sickness in small scale enterprises and analyze the relationships amongst the factors that shape survival or sickness as well as revival. A sample of 300 ownerscum entrepreneurs or promoters was assumed for the current research from across the three districts of Andhra Pradesh; which was subjected to likert based measurement instrument. The data hence collected was analyzed with aid of SPSS based explorative factor analysis and reliability was established with cronbach alpha estimation. The empirical and statistical analysis across AMOS lead to confirmatory factor analysis and enabled the identification of factors as "internal" and "external" contributions to the "market orientation" development, leading to changes and influences on the "ability to pay" and "threat from sickness". The sickness was hence attributed to internal, external as well as market orientation based factors that collectively shape the revival or the sickness across the incumbent units.
\end{abstract}

Keywords: Factor Analysis, SEM, SSI, Industrial Sickness, Internal Deficiencies, External dependencies, Entrepreneurs, Small business

The Small Scale sector is observed to contribute substantially towards the economy in short to long term growth prospects. The Small Scale sector in India comprises the entrepreneurial units that undertake risk and contribute towards the national and regional production of goods (Patil, 2011). The foremost feature of the small scale units (Dragnic, 2014) lies in their abilities to focus more on the personal and individual driven management attributes (owner and the manager are one and same person), usual restricted access to market as well as economic factors of production, face the impact of external factors like the state authorities, policy change by banking and credit institutions as well as the larger sensitivity towards the interference from state and other factors. The small scale sector despite its enormous potential in terms of contribution to economy and employment generation is not able to realize its potential up to the fullest. There are deviations and aspects, factors and dimensions that constrain the ability of the small scale enterprises and industrial units to exhibit their true potential (Lakshmi, 2013) in enlivening the local industrial base as well as achievement of economic self-sufficiency at local and regional level. In Andhra Pradesh, the state government is giving a push to SSI sector yet the sector is far from showing the results and outcomes that it is forecasted to project and exhibit. The review of existing literature highlights the crucial role of the 
internal organizational deficiencies and the external dependencies as impacting the unit based realization of the potential (Dragnic, 2014). The study across the Croatian enterprises and small scale industrial units interpreted the internal factors as life cycle stage, business enterprise size, technology and product driven innovation perspective, extent of organizational (unit based) autonomy, extent of formalization and centralization, market roles as well as resource usage patterns (Deshpande, 2004) as impacting the overall dynamics of sickness and decline in the overall financial performance.

\section{Construct definition}

There are a lot of factor that have been observed to be contributing towards the construct of "industrial sickness" across small scale units in context of developing economies like India. The organizational deficiencies (Chowdhary, 2012) seem to involve the aspects of management inefficiencies (Tuli, 2017), managerial deficiencies in decision making(Santana, 2017) are a part of the managerial perceptions (Gomez-Mejia, 1987). The existing literature remarks these organizational inefficiencies as impacting the implementation of the business model in timely manner across the segment market. The existing studies elaborate substantially on the psychological ad cognitive aspects as well as mindset approach to promoter's role in decision making and shaping the internal deficiencies and deficits.

In association, the external dependencies of the industrial unit (Mello, 2007) have been interpreted as non-intrinsic resource based dependencies that are essential to run the machinery, the assets, and the installed capacity as well as seek legitimate use of the equipments. The level of access to resources and factor endowments, the continuity and consistency of supply of core and desired economic resources, infrastructural goods and services, roads and telecom connectivity, vulnerability to state policy with regard to small scale sector and reliance on the domestic economic demand and lack of export market catering: are some of the most viable forms of the dependencies on the state and local customer base for revenue generation and likewise sustainability. The lesser capital intensity and higher labor intensity of small scale enterprises renders them susceptible to the external credit institutions and government bodies for subsidy, aid, financing as well as money based assistance in market access as well as market infrastructure development.

\section{Role of organizational deficiencies (Internal Factors)}

The managerial inefficiencies, financial mismanagement, inconsistent and non-durable assess to factors of production, technology driven factors and the infrastructure related factors have been recognized as the internal factors that contribute towards the firm based deficiencies in coping up with the business in turbulent environments (Brown, 2012). The "internally located and determined" deficiencies have been widely believed to play a larger role in determining the pattern of execution of the strategy, implementation of business model as well as the overall usage and allocation of the factors of production within the unit concerned (Dean, 2007). The business model execution is immensely effected by the predominant internal inefficiencies.

The existing literature classifies the unit based internal inefficiencies as comprising the managerial or owner's perspective, as involving the planning, cognitive mindsets and the cognitive frameworks (Gomez-Mejia, 1987) with regard to business opportunity sensing and development in most potential form and context.

\section{Role of unit's external dependencies (External Factors)}

The vulnerability of the unit's operations and functioning with regard to external factors consistently impacts the working and general progress of the firm in continuing the operations. With regard to developing economies, the periodic transitions in political regimes at state level often lead to changes in the policy framework with regard to small scale sector. This change has been observed to lead to a transition in the way the unit draws resources from across the economy and converts the resources into meaningful products and services (Dragnic, 2014). The inadequacy with regard to the availability of the resources, input factors, infrastructural factors, connectivity, supporting materials; has been observed to hamper the general functioning of the unit in question.

The dependence on the infrastructural goods and service (Cheng, 2015) dominate the small scale 
industry. The non-ability of the firm to continually access the liquid funds creates challenges in terms of work capital based leverage across the existing financial structure. The bank and unit's relationships (Waktola, 2016) constitute another area of dependence and conflict across the time. The inter-organizational sourcing and bargaining terms (Lahtinen, 2011) constitutes another sizable area of conflict and clash of interests that is often judicious to the inculcation of unit based decline in performance and unit based sickness. The external dependencies on supply chain partners (Sharma, 1985) are another area of observed constraint with regard to the effective and optimum functioning of the installed assets and the equipment across the premises. The MSME reports as well as SIDBI reports also highlight the crucial role of the state policy in prevention and removal of challenges with regard to the market access. The existing research also points towards the significant role of this factor (Tuli, 2017) as it impacts the industry structure, business activity in the industry cluster as well as the survival of the units.

\section{Literature Review}

The phenomenon of small scale entrepreneurship (Shetty, 1964) in Andhra Pradesh (Deepthi, 2012) is been conceptualized and operationalized in multiple facets. A study across Nellore district observed the incidence of the substantial impact of the aptitudes (capacity to bear risks, capability to forecast the prospects of enterprise, sense of confidence and competence in handling the odd situations) as vital for the small scale units to survive and face the competition from across the larger and established players in the market. The small business owners and promoters have an observed and reported history of non-indulgence in the strategic planning with regard to the performance management, competitiveness and market based orientation sustenance. The observed lack of business plan development (Bamfo, 2015) and lack of harnessing the strategic intent (Hamel, 2005) further seems to complicate the problems that arise cross the venture shelf life. The promoter has been envisioned as owing an extensive role in shaping the unit based strategy dynamics in small firms decide the consistency, the growth as well as survival prospects across the small business enterprise.
The term "strategy dynamics" essentially attributes to the patterns and scope of the dynamics of strategy drafting and execution as shaped by the promoter's (owner's) sense making with regard to existing environmental awareness, perceptions and cognitive frameworks (Waktola, 2016) with regard to the potential opportunities and threats as evident across the external environment. The associated entrepreneurial "uncertainty of knowing" (Atherton, 2003) as a factor was observed to count. The resource based perspective (Rangone, 1999) advocates the organizational capability viewpoint with regard to the small firm based abilities (Rangone, 1999) to decide and embark upon an appropriate course of action.

The organizational capability is widely regarded as the basis for the unit's potential to compete sustainably across the market platform. The behavioral biases in decision making (Yazdipour, 2010) and managerial heuristics (Atherton, 2003) are the cognitive processes and mechanisms that shape the decision making and sense making with regard to market dynamics and environmental uncertainties. The prevalence of asymmetrical information further complicates the decision making and the prospects for sustenance or failure of the small scale unit.

The small business and the small scale manufacturing units also need to rely on the competitive advantage to compete aggressively and consistently in the existing market driven environment (Dragnic, 2014). The unit based decision making (Sharifi, 2009) has often been regarded as central towards the unit's acquisition of the advantage as well as timely sustenance (Chowdhary, 2012) of such an advantage (Chopade, 2013) over larger periods of time.

Another study (Nimalathasan, 2008) on the prospective linkage between the owner's awareness of the surrounding environment and the respective impact on the small scale unit's performance across Sri Lankan enterprises revealed the incidence of the impact of the formal strategic planning on the unit based functioning and the economic performance as well.

The manager initiated "strategic consistency" (Lamberg, 2005) in unit based competitive behavior is being observed more an outcome of promoter's consistent engagement in strategy making than anything else. The subsequent phenomenon seems 
to possess consequences for the long term survival of the unit especially in context of small business enterprise. The promoter's perceptions of strategic planning (Gibcus, 2009), external dependencies (Brown, 2012) and internal deficiencies (Cheng, 2015) hence matter a lot in developing the promoter's awareness and understanding of the forces that shape and influence the business planning and strategy execution in unit's perspective in developing economies worldwide.

The promoter's planning and entrepreneurial orientation (Khelil S. 2012) is being observed as a key differentiator that separates the sick units from the non-sick units. The promoter's passion, intentions and inclinations for entrepreneurial growth have been observed as reviving and sustaining the business temperament and hence the inflow of revenues. Such promoter based perceptions may not be measured directly yet have been operationalized in existing studies with aid of the self-assessment of the entrepreneurs with regard to their traits (Chinomona, 2013), orientations (Cheng, 2015), skill sets (Atherton, 2003) and inclinations (Nimalathasan, 2008).

Such perceptions in existing literature (Khelil, 2012) have been reportedly operationalized with contextual specificity of the opinions, decisions and viewpoints of the owners. The ultimate objective in such studies as per existing literature is to explore the measurability and quantification of the linkages (Khelil, 2012) that lead to state of unit based failure or decline on account of the owner's attitude towards the business planning and unit based management.

Another study (Vani, 2017) enlisted the aspects of entrepreneurial ability to undertake risks, managerial capability, technological literacy, willingness to adopt new technology, readiness to seek opportunity, proficiency in managing public relations, ability to take decisions as important for entrepreneurial survival and sustenance. A study (Malyadri, 2014) on the economic appraisal of entrepreneurship across small scale units in Andhra Pradesh revealed the incidence of the substantial impact of the factors of motive, risk taking, status, innovation capability, rewards and qualification of entrepreneurial sustenance in turbulent business environment (Rao, 2014).
Some other studies (Chowdhary, 2012) highlight the crucial role (Vani, 2017) of the entrepreneurial inclinations (Dess, 1983), orientations (Lakshmi, 2013) and motivations (Mishra, 2013) as shaping the individual's propensity (Malyadri, 2014) to indulge in entrepreneurial activity (Sharma, 1985) and respective focus in small business perspective (Shetty, 1964) across developing economies.

\section{Measurement scales and Research Methodology}

The research premised these objectives:

- To identify the factors that contribute (directly and indirectly) towards the small scale industrialhealth (survival or decay) in Andhra Pradesh Industry

- To quantify the cross factor impact on organizational survival or sickness in small scale enterprises

The research adopted the empirical methodology of likert scale based primary data based approach in order to operationalize the aforesaid construct of small scale unit based sickness in state of Andhra Pradesh. The research was limited to three districts of East Godavari, West Godavari and Krishna districts. These districts were shortlisted on basis of the substantial small scale unit concentration as per the MSME list and other reports by the District Industry centers which focuses on the rise of sickness across the sample of 300 small scale units in these regions. The response considered for the current research was 155 . The research operationalized the construct with aid of three scale and profiling variables as mentioned here.

\begin{tabular}{|c|c|c|c|}
\hline & Subsets & Scale Description & $\begin{array}{l}\text { Cron Bach } \\
\text { Alpha }\end{array}$ \\
\hline A & 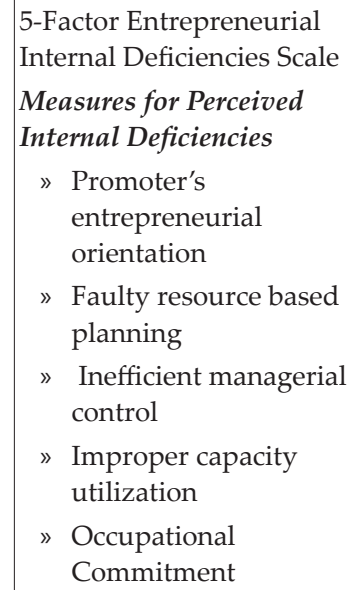 & $\begin{array}{l}\text { The first scale } \\
\text { concentrates on } \\
\text { the evaluation } \\
\text { of the "factors" } \\
\text { that directly } \\
\text { and indirectly } \\
\text { contribute towards } \\
\text { the incidence of } \\
\text { the unit based } \\
\text { sickness on account } \\
\text { of entrepreneur } \\
\text { driven inefficiencies } \\
\text { and deficiencies on } \\
\text { part of the owner/ } \\
\text { entrepreneur }\end{array}$ & .901 \\
\hline
\end{tabular}




\begin{tabular}{|c|c|c|c|}
\hline B & $\begin{array}{l}\text { 5-Factor Perceived External } \\
\text { Dependencies Scale } \\
\text { Measures for Perceived } \\
\text { External Dependencies } \\
\text { » Insufficient factor } \\
\text { endowments } \\
\text { » Infrastructural } \\
\text { bottlenecks } \\
\text { »Changes in economic } \\
\text { conditions } \\
\text { » Perceived policy } \\
\text { uncertainty and } \\
\text { governmental } \\
\text { support } \\
\text { Access to bank credit }\end{array}$ & $\begin{array}{l}\text { The second scale } \\
\text { concentrates on } \\
\text { the evaluation } \\
\text { of the "factors" } \\
\text { that directly } \\
\text { and indirectly } \\
\text { contribute towards } \\
\text { the incidence of } \\
\text { the unit based } \\
\text { sickness on account } \\
\text { of entrepreneur's } \\
\text { perceptions } \\
\text { of external } \\
\text { dependencies } \\
\text { and opinions of } \\
\text { contextual elements }\end{array}$ & .927 \\
\hline C & $\begin{array}{l}\text { 4-Factor Perceived Unit } \\
\text { based Outcomes Scale } \\
\text { Measures for Perceived Unit } \\
\text { based Outcomes } \\
\text { » Imbalance across } \\
\text { relationships with } \\
\text { stakeholders } \\
\text { » Lack of market } \\
\text { orientation of unit } \\
\text { » Decrease in ability } \\
\text { of unit to meet } \\
\text { expenses } \\
\text { » Perceived failure risk }\end{array}$ & $\begin{array}{l}\text { The third scale } \\
\text { concentrates on } \\
\text { the evaluation } \\
\text { of the "factors" } \\
\text { that directly } \\
\text { and indirectly } \\
\text { contribute towards } \\
\text { the incidence of } \\
\text { the unit based } \\
\text { sickness on account } \\
\text { of entrepreneur's } \\
\text { perceptions of } \\
\text { relationships with } \\
\text { stakeholders, } \\
\text { market orientation } \\
\text { of the unit, unit's } \\
\text { ability to meet the } \\
\text { expenses and unit } \\
\text { based survival / } \\
\text { failure risk }\end{array}$ & .931 \\
\hline D & Profiling Variables & $\begin{array}{l}\text { Unit based and } \\
\text { Entrepreneur based }\end{array}$ & \\
\hline
\end{tabular}

\section{Analysis}

\begin{tabular}{|l|l|}
\hline The Objectives & Method Used \\
\hline $\begin{array}{l}\text { To identify the factors that contribute (directly } \\
\text { and indirectly) towards the small scale } \\
\text { industrial health(survival or decay) in Andhra } \\
\text { Pradesh Industry }\end{array}$ & $\begin{array}{l}\text { Literature } \\
\text { Review } \\
\text { Measurement } \\
\text { Instrument }\end{array}$ \\
\hline $\begin{array}{l}\text { To quantify the cross factorial impact on } \\
\text { organizational survival or sickness in small } \\
\text { scale enterprises }\end{array}$ & Factor Analysis \\
\hline
\end{tabular}

The rationale for insistence on exploratory factor analysis stems from the observation that it could be a reliable and trusted method for data reduction as well as the data based summarization of the outcomes. The existing research on the usage of the exploratory factor analysis across likert based measurement instruments reveal the incidence of the need for data reduction and concise summarization of the vast data collected from across the primary data collection means. The entrepreneurs or promoter's entrepreneurial orientation and skills were observed to exhibit the maximum variance. The SPSS based principal component analysis revealed the incidence of diverse patterns and variances as mentioned in the pattern matrix below. The SPSS based factor driven pattern matrix reflects the cross district variations in perceptions of the surveyed entrepreneurs with regard to the "internal" scale elements.

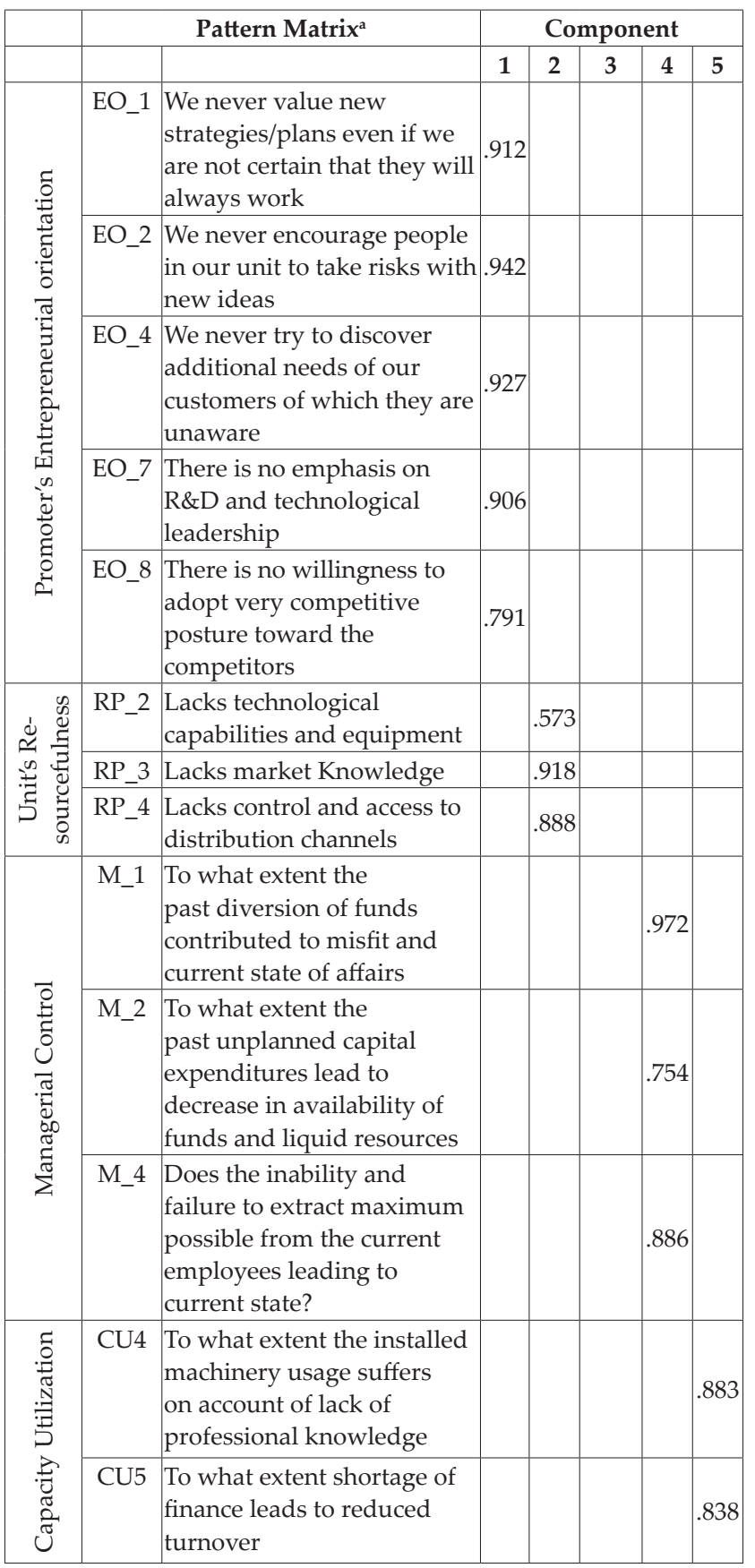




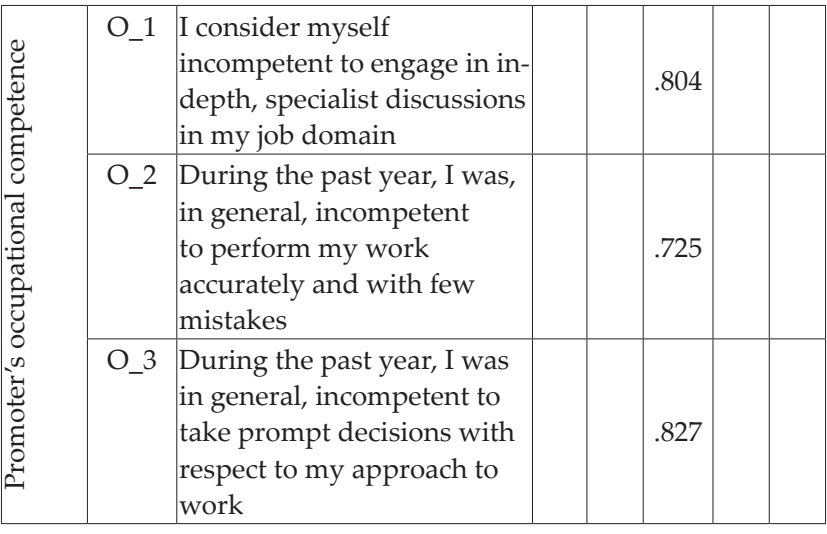

Extraction Method: Principal Component Analysis.

Rotation Method: Oblimin with Kaiser Normalization.

a. Rotation converged in 5 iterations.

With regard to unit's perceived external dependencies, the unit based assessment of access to and availability of the factor endowments exhibited maximum proportion of variance. This in other words means that the units in small scale sector in Andhra Pradesh seem to be immensely concerned about the timely and consistent access to and availability of the factor resources, essential to continue or to operate the machines for sustenance of manufacturing.

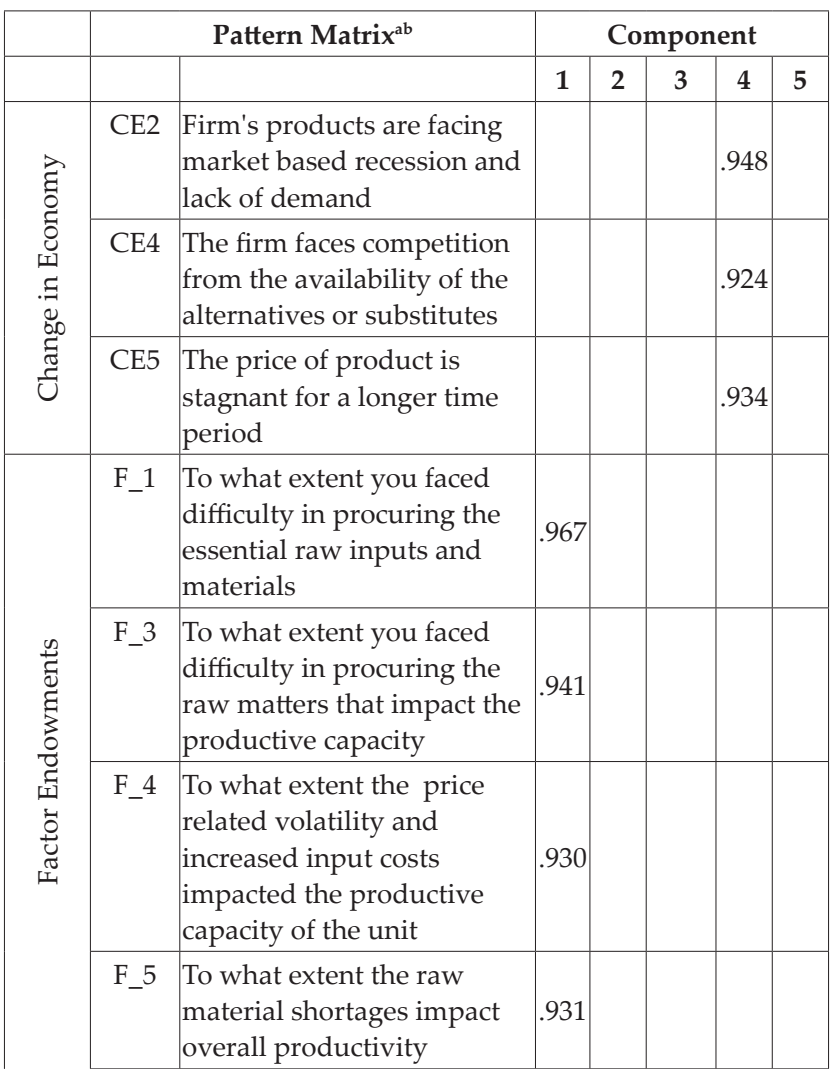

\begin{tabular}{|c|c|c|c|c|c|c|}
\hline & F_6 & $\begin{array}{l}\text { To what extent the non- } \\
\text { availability of local labor } \\
\text { impacts the productive } \\
\text { usage? }\end{array}$ & .912 & & & \\
\hline & F_7 & $\begin{array}{l}\text { To what extent the unit is } \\
\text { under financed in terms of } \\
\text { working capital and fixed } \\
\text { asset acquisition }\end{array}$ & .885 & & & \\
\hline \multirow{4}{*}{ 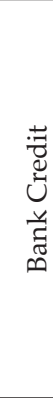 } & BCR_1 & $\begin{array}{l}\text { Bank loans are never easily } \\
\text { available for us }\end{array}$ & & & & .731 \\
\hline & & $\begin{array}{l}\text { Capital from suppliers or } \\
\text { customers is never easily } \\
\text { available for us }\end{array}$ & & & & .947 \\
\hline & BCR_3 & $\begin{array}{l}\text { Capital from other sources } \\
\text { is easily available for us }\end{array}$ & & & & .838 \\
\hline & BCR_5 & $\begin{array}{l}\text { Relative to competitors } \\
\text { we have no advantageous } \\
\text { financial resources }\end{array}$ & & & & .721 \\
\hline \multirow{5}{*}{ 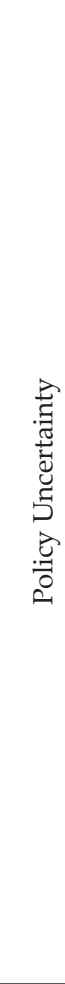 } & PU_1 & $\begin{array}{l}\text { There is no provision of } \\
\text { level playing field with } \\
\text { fiscal and non-fiscal } \\
\text { incentives for small } \\
\text { sector promotion, trade } \\
\text { agreements, export } \\
\text { promotion and tax holidays } \\
\text { and duty rationalization }\end{array}$ & & .946 & & \\
\hline & PU_3 & $\begin{array}{l}\text { There is no support for } \\
\text { strengthening value } \\
\text { chains and facilitation of } \\
\text { supporting ecosystem and } \\
\text { cluster for downward and } \\
\text { upward linkages }\end{array}$ & & .954 & & \\
\hline & PU_4 & $\begin{array}{l}\text { Large number of rules } \\
\text { and regulations for getting } \\
\text { concession, subsidy and aid } \\
\text { for industry establishment }\end{array}$ & & .965 & & \\
\hline & PU_5 & $\begin{array}{l}\text { No subsidy for asset } \\
\text { acquisition, purchase of } \\
\text { raw materials and skill } \\
\text { enhancement of labor }\end{array}$ & & .880 & & \\
\hline & PU_6 & $\begin{array}{l}\text { No waivers on stamp duty, } \\
\text { registration charges, taxes, } \\
\text { government charges for } \\
\text { tender participation }\end{array}$ & & .893 & & \\
\hline \multirow{3}{*}{ 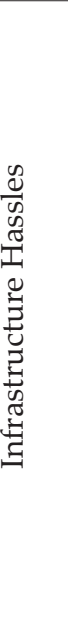 } & INF_1 & $\begin{array}{l}\text { To what extent there was } \\
\text { incomplete and poor } \\
\text { quality access to power } \\
\text { supply at your end }\end{array}$ & & & -.955 & \\
\hline & INF_2 & $\begin{array}{l}\text { How far and how } \\
\text { occasionally you } \\
\text { face transportation } \\
\text { and communication } \\
\text { problems at your } \\
\text { industrial premises? }\end{array}$ & & & -.849 & \\
\hline & INF_3 & $\begin{array}{l}\text { In wake of larger } \\
\text { and longer access to } \\
\text { consumption markets, } \\
\text { how occasionally you } \\
\text { maintain inventories }\end{array}$ & & & -.889 & \\
\hline
\end{tabular}


INF_4 To what extent are municipal and industrial water usage and power tariffs fair to small scale units in state

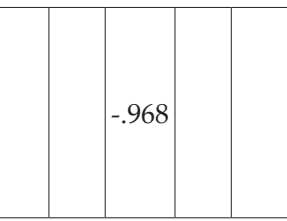

Extraction Method: Principal Component Analysis.

Rotation Method: Oblimin with Kaiser Normalization.

a. Rotation converged in 6 iteration

The unit based market orientation exhibited maximum observed variance amongst the scale items. The following pattern matrix depicts the factor loadings with regard to the assumed factors.

\begin{tabular}{|c|c|c|c|c|c|c|}
\hline & & Pattern Matrix ${ }^{a b}$ & & om & one & \\
\hline & & & 1 & 2 & 3 & 4 \\
\hline \multirow{6}{*}{ 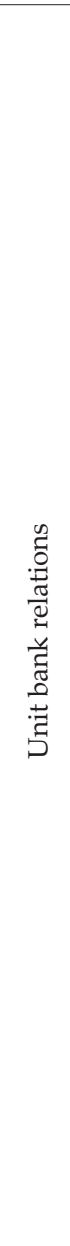 } & UBR3 & $\begin{array}{l}\text { We can never freely share } \\
\text { concerns and problems } \\
\text { about the unit and know } \\
\text { that they will respond } \\
\text { constructively }\end{array}$ & & .969 & & \\
\hline & UBR4 & $\begin{array}{l}\text { We can never freely share } \\
\text { the concerns and problems } \\
\text { regarding our unit and } \\
\text { know that they will be } \\
\text { interested in listening }\end{array}$ & & 937 & & \\
\hline & UBR5 & $\begin{array}{l}\text { We never share common } \\
\text { business values with the } \\
\text { bank }\end{array}$ & & 982 & & \\
\hline & UBR6 & $\begin{array}{l}\text { We feel that the bank } \\
\text { will never act in a fashion } \\
\text { consistent with what we } \\
\text { recommend without prior } \\
\text { discussion with us }\end{array}$ & & 973 & & \\
\hline & UBR7 & $\begin{array}{l}\text { Senior manager/promoter } \\
\text { has no regular meetings } \\
\text { with bankers }\end{array}$ & & .956 & & \\
\hline & UBR8 & $\begin{array}{l}\text { Our website is } \\
\text { never updated with } \\
\text { comprehensive } \\
\text { management } \\
\text { communications aimed at } \\
\text { bankers }\end{array}$ & & 907 & & \\
\hline \multirow{3}{*}{ 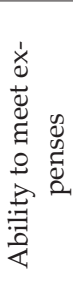 } & AME1 & $\begin{array}{l}\text { The unit pays the obligations } \\
\text { with difficulty as cash position } \\
\text { is rarely monitored }\end{array}$ & & & & 1.016 \\
\hline & AME2 & $\begin{array}{l}\text { The unit is unable to meet } \\
\text { operating costs }\end{array}$ & & & & .737 \\
\hline & AME3 & $\begin{array}{l}\text { The unit is unable to pay for } \\
\text { acquiring the essential inputs }\end{array}$ & & & & .762 \\
\hline
\end{tabular}

Extraction Method: Principal Component Analysis.

Rotation Method: Oblimin with Kaiser Normalization.

a. Rotation converged in 5 iterations.

\section{Modeling of Impact}

The cross factor modeling of impact yielded these causal relationships across the variables. As evident in the cross factor correlation matrix, these are correlating with each other. The same was evident in the AMOS based modeling with regard to the constituent factors "promoter's entrepreneurial orientation", "faulty resource based planning", "inefficient managerial control", "entrepreneur's occupational commitment" and "improper capacity utilization". The promoter's entrepreneurial orientation seems to lead to 0.4 times increase in promoter's occupational commitment as well as 0.6 times increase in promoter's resource planning abilities and 0.2 times increase in capacity utilization 
abilities. The entrepreneur's perceived lack of entrepreneurial orientation (EO) was observed to lead to a 0.2 times increase in the unit based capacity utilization (CU). In lateral terms, the relationship calls for negative and positive interpretation. The "presence" of promoter's constructive "entrepreneurial orientation" does lead to "affective capacity utilization" yet the "decreased levels" of the entrepreneur's inherent and self-assessed "entrepreneurial orientation" does point towards the "lower" capacity utilization in totality. The data analysis reported the promoter initiated resource planning (RP) as leading to a 0.4 times increase in the unit based managerial control (M). In simpler terms this is equivalent to saying that the promoter's active resource planning encourages control of the unit whereas the lack of resource based planning by the promoter (entrepreneur) often leads to a decrease in the promoter's exercise of control over the unit's functioning. With regard to monitoring and assessing the cross factor relations across the "external dependency" scale elements, the AMOS modeling was undertaken across the constituent factors of "insufficient factor endowments", "infrastructural bottlenecks", "changes in economic conditions" and the "pattern of relationships with banks (stakeholders)". Promoter's perceived sense of changes in market was observed to lead to 0.5 times increase in the respective entrepreneur's perception of policy related uncertainty (PU) in general.

\section{Path Coefficients}

\begin{tabular}{|l|l|l|l|l|}
\hline & Path & & $\begin{array}{l}\text { Regres- } \\
\text { sion Es- } \\
\text { timates }\end{array}$ & $\begin{array}{l}\text { Stan- } \\
\text { dard- } \\
\text { ized }\end{array}$ \\
\hline $\begin{array}{l}\text { Occupational } \\
\text { Commitment (O) }\end{array}$ & $\leftarrow$ & $\begin{array}{l}\text { Entrepreneurial } \\
\text { Orientation (EO) }\end{array}$ & 0.445 & 0.205 \\
\hline Resource Planning (RP) & $\leftarrow$ & $\begin{array}{l}\text { Entrepreneurial } \\
\text { Orientation (EO) }\end{array}$ & 0.63 & 0.511 \\
\hline Factor Endowment (F) & $\leftarrow$ & $\begin{array}{l}\text { Infrastructural } \\
\text { Hassles (INF) }\end{array}$ & 0.335 & 0.424 \\
\hline Resource Planning (RP) & $\leftarrow$ & $\begin{array}{l}\text { Occupational } \\
\text { Commitment (O) }\end{array}$ & 0.012 & 0.022 \\
\hline Managerial Control (M) & $\leftarrow$ & $\begin{array}{l}\text { Resource Planning } \\
\text { (RP) }\end{array}$ & 0.473 & 0.496 \\
\hline Bank Credit (BCR) & $\leftarrow$ & $\begin{array}{l}\text { Factor } \\
\text { Endowment (F) }\end{array}$ & 0.217 & 0.291 \\
\hline Policy Uncertainty (PU) & $\leftarrow$ & $\begin{array}{l}\text { Changes in } \\
\text { Economy(CE) }\end{array}$ & 0.589 & 0.336 \\
\hline $\begin{array}{l}\text { Unit stakeholder } \\
\text { Relations (UBR) }\end{array}$ & $\leftarrow$ & $\begin{array}{l}\text { Factor } \\
\text { Endowment (F) }\end{array}$ & 0.087 & 0.075 \\
\hline
\end{tabular}

\begin{tabular}{|l|l|l|l|l|}
\hline $\begin{array}{l}\text { Unit stakeholder } \\
\text { Relations (UBR) }\end{array}$ & $\leftarrow$ & $\begin{array}{l}\text { Infrastructural } \\
\text { Hassles (INF) }\end{array}$ & 0.575 & 0.627 \\
\hline $\begin{array}{l}\text { Unit stakeholder } \\
\text { Relations (UBR) }\end{array}$ & $\leftarrow$ & Bank Credit (BCR) & 0.282 & 0.181 \\
\hline $\begin{array}{l}\text { Capacity } \\
\text { Utilization(CU) }\end{array}$ & $\leftarrow$ & $\begin{array}{l}\text { Entrepreneurial } \\
\text { Orientation (EO) }\end{array}$ & 0.248 & 0.416 \\
\hline $\begin{array}{l}\text { Capacity Utilization } \\
\text { (CU) }\end{array}$ & $\leftarrow$ & $\begin{array}{l}\text { Managerial } \\
\text { Control (M) }\end{array}$ & 0.225 & 0.445 \\
\hline $\begin{array}{l}\text { Unit stakeholder } \\
\text { Relations (UBR) }\end{array}$ & $\leftarrow$ & $\begin{array}{l}\text { Policy Uncertainty } \\
\text { (PU) }\end{array}$ & 0.107 & 0.112 \\
\hline $\begin{array}{l}\text { Market Orientation } \\
\text { (MOF) }\end{array}$ & $\leftarrow$ & $\begin{array}{l}\text { Capacity } \\
\text { Utilization (CU) }\end{array}$ & 0.608 & 0.65 \\
\hline $\begin{array}{l}\text { Market Orientation } \\
\text { (MOF) }\end{array}$ & $\leftarrow$ & $\begin{array}{l}\text { Entrepreneurial } \\
\text { Orientation (EO) }\end{array}$ & 0.167 & 0.301 \\
\hline $\begin{array}{l}\text { Market } \\
\text { Orientation(MOF) }\end{array}$ & $\leftarrow$ & $\begin{array}{l}\text { Unit stakeholder } \\
\text { Relations (UBR) }\end{array}$ & 0.054 & 0.154 \\
\hline $\begin{array}{l}\text { Ability to Meet } \\
\text { Expenses (AME) }\end{array}$ & $\leftarrow$ & $\begin{array}{l}\text { Market } \\
\text { Orientation (MOF) }\end{array}$ & 1.577 & 0.838 \\
\hline Failure Risk(FP) & $\leftarrow$ & $\begin{array}{l}\text { Unit stakeholder } \\
\text { Relations (UBR) }\end{array}$ & 0.218 & 0.15 \\
\hline
\end{tabular}

Source: AMOS based modeling of relationships with version 20.0.

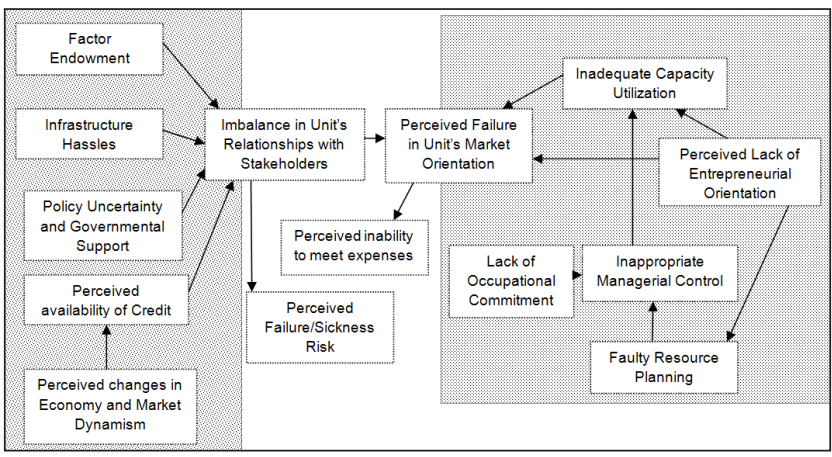

Fig. 1: Hypothetical relations

Source: Self-Devised

\section{Findings}

The current research envisages the task of identification of the factors that contribute (directly and indirectly) towards the small scale industrial sickness in Andhra Pradesh Industry. The current research posited itself across the ideology that contextual elements define and determine the current state of affairs with regard to economic performance. The degradation of the performance and the state of sickness is not a standalone or a self-built problem yet it is widely believed to owe its existence (Dragnic, 2014) to the contexts and the dimensions that are present in the nearby environment of the firms. The internal factors primarily the promoter's decision making and the external factors primarily the surrounding environment does stimulate the instance and the 
prospects for the firm based sickness or revival or turnaround in stressful times. The current study posited itself in the Khelil's and Smida's three key dimensions that are conceptualized to impact the small business survival or failure rates. The first dimension revolves around the contexts (environment) in which the enterprise or the unit functions. The second dimension comprises the centrality of the resources in achieving the goals. The third aspect constitutes the orientations and the motivations of the entrepreneur who is supposed to decide and act strategically

The contributing factors never ever operate unilaterally or in a one-way manner yet they do impact and shape the phenomenon in multiple manners. The research quantified the cross factorial impact on organizational sickness in small scale enterprises. This is significant in the terms that cross factor impact would be evaluated and analyzed in terms of empirical basis and numerical approach. The quantification serves to facilitate the interpretation of the cross linkages in state and local as well as regional context.

\section{REFERENCES}

Atherton. 2003. The uncertainty of Knowing: An analysis of the nature of knowledge in a small business context. Human Relations.

Bamfo, A. 2015. Planning in Small Businesses: The perspectives of Owners Managers. International Journal of Entrepreneurship and Small Business Management.

Brown, K. 2012. The effect of internal control deficiencies on the usefulness of earnings in executive compensation management. Advances in Accounting.

Cheng, G. 2015. Internal control and operational efficiency. European Accounting Association Publication.

Chinomona. 2013. Business Owner's Expertise,Employee Skills Training and Business Performance: A small business perspective. Journal of Applied business research, 29 (6).

Chopade. 2013. Growth and Sickness of Small Scale Industries in India. World Research Journal of Economics, 2(1).

Chowdhary. 2012. Empirical study on the reasons of Industrial Sickness: Jammu and Kashmir. IOSR Journal of Business and Management.

Dean, M. 2007. Toward a theory of sustainable entreprneurship: Reducing environmental degradation through entreprenurial action. Journal of Business Venturing, 22.
Deshpande, F. 2004. Organizational culture,market orientation, Innovativeness and Firm Performance: An international research odyssey. International Journal of Research in Marketing, 21.

Dragnic. 2014. Impact of Internal and External factors on the performance of small and medium businesses. Journal of Contemporary management issues.

Gibcus, V. 2009. Strategic decision making in small firms: A taxonomy of small business owners. International Journal of Entrepreneurship and Small Business, 7 (1).

Gomez-Mejia, T. 1987. Managerial Control, Performance and Executive Compensation. Academy of Management Journal, 30.

Hamel, P. 2005. Strategic Intent. Harvard Business Review.

Khelil, S. 2012. Contribution to the understanding of the failure of new businesses: A qualitative exploration of the multiple dimensions of the phenomenon. Review of Entrepreneurship, 11 (1).

Lahtinen, T.H. 2011. Resource Usage Decisions and Business Success. Journal of Forest Products Business Research, 6(3).

Lakshmi. 2013. The performance of small scale industries in India. Fact and You.

Lamberg. 2005. Competitive Dynamics, Strategic Consistency and Organizational Survival.

Mello. 2007. External Dependencis, Relational Resources and Performance Hetereogenity in Emerging Economies. EnANPAD.

Nimalathasan. 2008. A study of owner-manager's environmental awareness and small business performance.

Patil. 2011. Role of Small Scale Industries in Economic Development.

Rangone. 1999. A resource based approach to strategy analysis in small medium sized enterprises. Small Business Economics, 12.

Santana. 2017. Turnaround strategies for companies in crisis: The causes of decline. BRQ Business Research Quarterly, 20.

Sharifi, Z. 2009. Sense making and recipies: Examples from selected small firms. International Journal of Entrepreneurail Behaviour and Research, 15(6).

Sharma. 1985. Industrial Sickness in India: An analysis. ASCI Journal of Management, 15(1).

Tuli, A. 2017. Identifying organizational deficiencies through root cause analysis. Nuclear Technology.

Waktola, H. 2016. Analysis of main cause for the entreprneeur's drop out in micro and small enterprises. International Journal of Economics and Management Sciences, 5(6).

Yazdipour, C. 2010. Predicting Firm Failure: A behavioural finance perspective. The Journal of Entrepreneurial Finance. 
